\title{
SZÜRKEVÍZ MINTÁK SZÛ́RÉSSEL TÖRTÉNŐ KEZELÉSI ELJÁRÁSAINAK VIZSGÁLATA
}

\section{ANALYSIS OF GREYWATER SAMPLES TREATED BY FILTRATION}

\author{
Ungvári Csaba ${ }^{1}$, Izbékiné Szabolcsik Andrea ${ }^{2}$, Bodnár Ildikó ${ }^{3}$ \\ Debreceni Egyetem, Müszaki Kar, Környezetmérnöki Tanszék, 4028 Magyarország, \\ Debrecen, Ótemetö utca, 2-4 \\ ${ }^{1}$ csaba.ungvari31@gmail.com \\ 2szabolcsikandi@eng.unideb.hu \\ 33odnari@eng.unideb.hu
}

\begin{abstract}
In our research we pre-treated synthetically produced greywaters with filtration on various filters. We characterised the quality of greywater samples with several parameters. We investigated these parameters on the untreated and pre-treated samples as well. We evaluated the efficiency of the treatments by measuring the characteristic parameters. It was shown, that the most effective pre-treatment for the greywater's preparation for reuse is the filtration on silica sand or activated charcoal and silica sand combined filter media.
\end{abstract}

Keywords: greywater, reuse, artificial bathwater, filtration.

\section{Összefoglalás}

Vizsgálataink során szintetikusan előállított szürkevizek különböző szűrőközegeken történő előkezelését végeztük el. A szürkevíz mintákat többféle vízminőségi paraméter mérésével jellemeztük. Ezeket a vizsgálatokat elvégeztük a kezeletlen illetve előkezelt mintákon is. A vízminőségi paraméterek változásainak segítségével következtettünk a különböző kezelések hatékonyságára. A vizsgálataink során kapott eredmények alapján megállapítható, hogy a fürdővizek újrafelhasználásának céljából a kvarchomokból- vagy az aktív szénből és kvarchomokból álló kombinált szürőközegen történő szürés bizonyult a leghatékonyabb előkezelési eljárásnak.

Kulcsszavak: szürkevíz, újrafelhasználás, szintetikus fürdőviz, szürés.

\section{Bevezetés}

Az édesvízkészleteink végesek, így egyre nagyobb globális problémát jelent a fokozódó vízhiány. Tovább súlyosbítja a problémát, hogy egyes édesvízlelőhelyek antropogén vagy természetes okból kifolyólag elszennyeződnek, és csak megfelelö kezelési technológiák alkalmazásával válnak felhasználhatóvá. A technológiák fejlődésének köszönhetően az energiaigénye- inkkel párhuzamosan a vízigényünk is folyamatosan nő, így a probléma fokozódik. Ezen probléma megoldására, mérséklésére számos törekvést tesznek a szakemberek. Például a szennyezett vízforrások tisztításával illetve a sós tengervíz sótartalmának eltávolításával újabb alternatív vízforráshoz juthatunk, azonban a vízhiány fokozódása nagyobb mértékü, mint ezeknek a törekvéseknek az eredményei [1]. Ezeken túlmenően alternatív vízforrás lehet még a háztartási 
szinten keletkező szürkevizek kezelése és újrahasználata is.

\section{A szürkevíz}

Szürkevíznek (greywater) nevezzük a háztartásban keletkező hulladékvizeket, amelyek fürdés, mosás, és konyhai tevékenységek során keletkeznek, és ezen vizek nem tartalmazzák a WC-k öblítéséböl származó szennyvizeket. Egy före vetítve az átlagos szennyvízkibocsátás 150-250 liter/nap, amelyböl a szürkevíz mennyisége 75-90\%-ot jelent, attól függően, hogy pl. mennyire víztakarékos az épületbe telepített WC. Európában a keletkező szürkevíz mennyisége 35-150 liter/fö/nap között mozog [2]. Ha a kezelt szürkevizet pl. a WCöblítésre használnánk, a napi vízfogyasztás akár 30\%-kal csökkenthetö lenne [3]. Magyarországon az átlagos vízfogyasztás 100110 liter/fö/nap, ami nagyobb városokban ennél több is lehet, kisebb városokban pedig 50-70 liter/fö/nap között alakul [4].

A nemzetközi szakirodalomban a szürkevizeket két nagyobb csoportba sorolják, amelyet a szennyezettség mértéke alapján light és dark jelzővel illetnek. Így megkülönböztetnek egy kevésbé terhelt (light greywater) és egy terheltebb (dark greywater) típust. Az ún. „light greywater” frakció a szürkevizek kevésbé szennyezett részét jelenti, például a fürdővizeket, amelyek szappanokból, tusfürdőkböl, úgynevezett detergenseket, emellett a bőrről, hajról és testről származó zsírokat tartalmaznak [5]. A mosásból vagy mosogatásból (dark greywater) származó szürkevíz nagy koncentrációban tartalmaz kémiai anyagokat a mosogató- illetve mosóporokból, fehérítőkből, zsírokból, olajokból, ruhafestékekből származó komponenseket és emellett pl. ruhákból nem lebomló szöveteket, továbbá ételmaradékokat is [2]. A Debreceni Egyetem Müszaki Karának Környezetmérnöki Tanszékén korábban zajló kutatások során megállapítást nyert, hogy ezen frakciók közül a fürdés, tisztálkodás során keletkező szürkevizek minőségi paraméterei állnak a legközelebb az ivóvíz minőséghez, illetve az összes keletkező háztartási szürkevíz közel 50 százalékát alkotja, [4,6] ezért ezen frakció kezelésének vizsgálatát tüztük ki célul.

\section{Anyag és módszer}

Vizsgálataink alkalmával a Debreceni Egyetem Müszaki Karának Környezetmérnöki Tanszékén korábbi évek kutatásai során kifejlesztett ivóvíz alapú, állandó összetételü szintetikus fürdővizeket készítettünk és használtunk, melyek összetételükben jól jellemzik a háztartásokban keletkező szürkevizeket. Az elkészített szintetikus fürdővizeket ezután szüréssel, mint jól ismert mechanikai szennyvízkezelési eljárás alkalmazásával kezeltük. A szintetikus fürdővízből előkezelés céljából egyenlő térfogatokat 4 féle szürőközegen engedtük át: természetes zeoliton, kvarchomokon, aktív szén és kvarchomok, ill. természetes zeolit és kvarchomok kombinált szürőközegeken. Az általunk létrehozott szürörendszer elvi rajza az 1. ábrán látható.

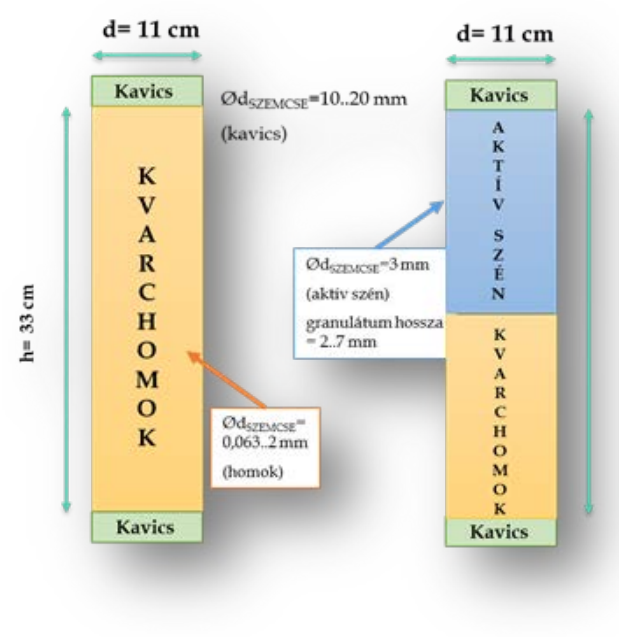

1. ábra. A szürörendszer elvi vázlata 
A kezeletlen, kezelt fürdővíz és ivóvíz minták vízminősítése során következő paraméterek változását követtük nyomon: $\mathrm{pH}$, zavarosság, zéta-potenciál, vezetöképesség, biológiai oxigénigény $\left(\mathrm{BOI}_{5}\right)$, kémiai oxigénigény (KOI), oldott szerves széntartalom (DOC). A minősítést követően megvizsgáltuk az említett paramétereket és azok változásából vontuk le következtetéseket.

\section{Kutatás eredménye}

Szürkevizek újrafelhasználásának tekintetében az irányelvek a legfontosabb minősítési paraméterként a $\mathrm{BOI}_{5}$, pH és zavarosság értékek vizsgálatát írják elő. Az USAban érvényben lévő szabályozás szerint a zavarosság értéke átlagban 2 NTU, maximum pedig $5 \mathrm{NTU}$, a BOI $10 \mathrm{mg} / \mathrm{l}$ alatti és a pH 6-9 közötti értékü lehet [2, 7, 8]. Ezen okból kifolyólag jelen tanulmányban a zavarosság, a pH és a $\mathrm{BOI}_{5}$ vizsgálati eredményeit mutatjuk be részletesen.

A 4 méréssorozat során kapott paraméterek átlageredményein keresztül mutatjuk be a szürőközegek szürkevizek összetételére gyakorolt hatásait.

A pH értéke meghatározza, hogy egy oldat savas, semleges vagy bázikus tulajdonságú, illetve az értéke alapján következtetni lehet az oldatban levő hidrogén ionok mennyiségére [8, 9]. A kezeletlen szürkevíz minta pH-ja a négy méréssorozat során átlagban 7,74-nek adódott. A szürési eljárások ezt az értéket legtöbb esetben kis mértékben megemelték. Legnagyobb mértékben a kvarchomokon történő szürés alkalmával emelkedett meg a $\mathrm{pH}$, ekkor átlagban 8,09 lett az érték. A többi szürőközeg esetében a növekedés nem volt szignifikáns, természetes zeoliton történő szüréskor a $\mathrm{pH}$ 7,91-nek, természetes zeolit és kvarchomok kombinált szürőközeg esetén 7,96-nak adódott. Az aktív szén és kvarchomok kombinált szürőközeg a $\mathrm{pH}$ értékét kis mértékben csökkentette a nyers mintához képest, ebben az esetben az átlagos szürést követő $\mathrm{pH}$ érték 7,60 lett.

A zavarosság mérése során az oldatban található oldhatatlan komponensek mennyiségét mérjük, amely azért lényeges, mert az oldhatatlan komponensek nagy mennyisége káros lehet a vízi életközösségekre. A zavarosság mértékét NTU-ban adjuk meg, mely jól reprezentálja a szürőközegek hatásfokát [8, 9]. A szüretlen minták esetén a zavarosság átlagosan 41,50 $( \pm 9,10)$ NTU-nak adódott. Ezen az értéken az általunk használt szürőközegek jelentős mértékben csökkentettek. A legkisebb csökkenés a természetes zeoliton történő szürés során következett be, ezen eljárások során 22,06 $( \pm 7,78)$ NTU-ra csökkent a zavarosság értéke. A másik három szürőközeg esetében a zavarosság értéke minden esetben szignifikánsan változott, a természetes zeolit és kvarchomok kombinált szürőközeg használatakor az átlagos érték 2,30 $( \pm 1,54)$ NTU lett, míg a kvarchomok $(1,56( \pm 0,24)$ NTU), illetve az aktív szén és kvarchomok kombinált szürőközeg $(1,68( \pm 0,31)$ NTU) használata során minden esetben a szabályozásban megfogalmazott 2 NTU alá sikerült csökkentenünk a zavarosság értékét.

A biológiai oxigénigény azt az oldott oxigénmennyiséget jelenti, amely a vízben levő szerves anyagok aerob baktériumok általi lebontásához 5 nap alatt $20^{\circ} \mathrm{C}$-on szükséges [8, 9]. A vizsgálataink során a szüretlen szürkevíz minták átlagos $\mathrm{BOI}_{5}$ értéke 102,08 $( \pm 19,78) \mathrm{mg} / \mathrm{l}$ volt. A szürési eljárások hatására ez az érték jelentősen nem csökkent, nem közelítette meg a határértéket, sőt a természetes zeolit szürőközeg esetében az elszennyeződés következtében átlagosan 168,73 $( \pm 24,71) \mathrm{mg} / \mathrm{l}$-re növekedett a fent említett érték. A legnagyobb csökkenés az aktív szén és homok kombinált szürőközegek esetében értük el, ebben az esetben az eredeti érték a szürés hatására $47,08( \pm 7,10) \mathrm{mg} / \mathrm{l}-$ re csökkent. 


\section{Következtetések}

A kapott eredmények kapcsán megállapíthatjuk a következőket:

- A fenti eredményekből jól látható, hogy a két legfontosabb szürkevíz újrafelhasználásra vonatkozó paraméter közül a zavarosság értékét az általunk használt szüröközegek közül a kvarchomok szürőközeg, illetve az aktív szén és kvarchomok kombinált szürőközeg minden esetben a határérték alá csökkentette. A természetes zeolittal történő szürés esetén átlagosan 48\%-kal, a kvarchomok ill. az aktív szén és kvarchomok kombinált szüröközegnél 96\%-kal, a zeolit és kvarchomok kombinált szürőközeg esetében 94\%-kal. Ezen adatok alapján elmondható, hogy a zeolittal történő szürés kivételével az öszszes szürési eljárás eltávolítja a zavarosságot okozó oldhatatlan komponensek nagy részét.

- A biológiai oxigén igény értékét önmagában a szürőközegek nem voltak képesek a határérték alá csökkenteni, ezért a szürés csak előkezelési eljárásként használható.

- A BOI ${ }_{5}$ értéke a szürési eljárások során a zeoliton történő szürés kivételével mindig csökkent, a zeolit esetében a növekedést véleményünk szerint a szürőközeg szenynyezettsége okozza. A többi szüröközeg esetében a $\mathrm{BOI}_{5}$ csökkenése átlagban kvarchomokon történő szürés alkalmazásánál 29\%, aktív szén és kvarchomok kombinált szürőközegnél $51 \%$, zeolit és kvarchomok kombinált szürőközeg esetén $19 \%$ volt.

- A pH értékek minden esetben 6-9 közötti tartományba estek.

További kezelésként lehetséges alternatíva lehet az oxidatív kezelés, amellyel az elözetes vizsgálataink alapján $10 \mathrm{mg} / \mathrm{l}$ alá csökkenthető a $\mathrm{BOI}_{5}$ értéke. Emellett másik alternatíva szürkevizek további kezelésére a koagulálás, amelynek szüréssel történő kombinálásával szintén nagy hatásfokkal távolíthatóak el a szerves illetve a szervetlen szennyezőanyagok a szennyvízböl.

\section{Köszönetnyilvánítás}

A publikáció elkészítését az EFOP3.6.1-16-2016-00022 számú projekt támogatta. A projekt az Európai Unió támogatásával, az Európai Szociális Alap társfinanszírozásával valósult meg.

\section{Szakirodalmi hivatkozások}

[1] „United Nations,” 24 november 2014. http://www.un.org/waterforlifedecade/scarcity.sht ml. [Hozzáférés dátuma: 22 október 2017].

[2] Ghaitidak, D. M., \& Yadav, K. D. (2013). Characteristics and treatment of greywater-A review. Environmental Science and Pollution Research, 20(5), 2795-2809.

[3] Penn, R., Schütze, M., \& Friedler, E. (2013). Modelling the effects of on-site greywater reuse and low flush toilets on municipal sewer systems. Journal of environmental management, 114, 7283.

[4] Szerk: Ferenc, Kalmár „Fenntartható energetika”, Budapest: Akadémiai Kiadó, 2014. 167-201.

[5] Noah, M. (2002). Graywater use still a gray area. Journal of environmental health, 64(10), 22.

[6] Bodnar, I., Szabolcsik, A., Baranyai, E., Uveges, A., Boros, N. (2014). Qualitative Characterization of the Household Greywater in Northern Great Plain Region of Hungary Environmental Engineering and Management Journal, Vol. 13, N.11. 2717-2724.

[7] Boyjoo, Y., Pareek, V. K., \& Ang, M. (2013). A review of greywater characteristics and treatment processes. Water Science and Technology, 67(7), 1403-1424.

[8] Boros, N.; Szabolcsik, A,; Bodnár, I,: Greywater treatment and reuse possibilities in household. Debreceni Egyetem, Proceedings of DENZERO International Conference, 2014, 193-200.

[9] Morel A. and Diner S., Greywater management in Low and Middel-Income Countries Review of different treatment systems for households or neighbourhoods, Swiss Federal Institute of Aquatic Scien. and Techn. (Eawag), Dubendorf, Switzerland, 2006. 